\title{
Outbreak of monensin poisoning in cattle due to supplementation error
}

\section{Eric Saymom Andrade Brito ${ }^{1^{*}}$. Tainá Gottschalk Andrade ${ }^{2}$ Cairo Henrique Sousa de Oliveira ${ }^{2}$ Veridiana Maria Brianezi Dignani de Moura ${ }^{1}$}

${ }^{1}$ Setor de Patologia Animal, Universidade Federal de Goiás (UFG), Escola de Veterinária e Zootecnia, 74690-900, Goiânia, GO, Brasil. E-mail: ericbrito.vet@gmail.com.*Corresponding author.

${ }^{2}$ Setor de Medicina Veterinária Preventiva, Universidade Federal de Goiás (UFG), Escola de Veterinária e Zootecnia, Goiânia, GO, Brasil.

ABSTRACT: Iatrogenic intoxications occur in domestic animals. Mortality was observed in a group of calves, reaching 20 deaths until the day of the technical visit, with or without sudden clinical signs, on a farm in the city of Pires do Rio, State of Goiás, Brazil. Deaths after the visit were not accounted systematically. Clinical signs included muscle weakness, ataxia, recumbency, bilateral jugular distention, and death. Suspected diagnosis of poisoning by ionophore antibiotics was made based on clinical and laboratory findings from nine animals, which included high plasma CK and LDH levels, as well as on anatomopathological findings of a recently dead calf, which showed myocardial and skeletal muscle degeneration and necrosis. Monensin overdose (25.5 $\mu \mathrm{g} / \mathrm{kg}$ in skeletal muscle and $209.4 \mu \mathrm{g} / \mathrm{kg}$ in the liver) was detected by liquid-chromatography and mass-spectrophotometry analysis, contributing to the confirmation of ionophore poisoning diagnosis.

Key words: antibiotics, bovine, ionophore, muscle necrosis.

Surto de intoxicação por monensina em bovinos devido a erro de suplementação

RESUMO: Intoxicações iatrogênicas ocorrem em animais domésticos. Um lote de bezerros apresentou mortalidade, chegando a 20 mortes até o dia da visita técnica, após sinais clínicos súbitos ou ausência destes, em uma propriedade rural do município de Pires do Rio, estado de Goiás, Brasil. As mortes após a visita não foram sistematicamente contabilizadas. Os sinais incluíam fraqueza muscular, ataxia, decúbito, distensão bilateral da veia jugular e morte. Baseado nos achados clínicos e laboratoriais de nove bovinos, que incluíram níveis de CK e LDH elevados no plasma, assim como degeneração e necrose miocárdica e na musculatura esquelética à avaliação anatomopatológica em um dos bezerros mortos, que apresentou degeneração e necrose em miocárdio e músculo esquelético. Uma sobredosagem de monensina (25,5 $\mu$ g/g no músculo esquelético e 209,4 $\mu \mathrm{g} / \mathrm{g}$ no fígado) foi detectada com análise por cromatografia líquida e espectrofotometria de massas, contribuindo para a confirmação do diagnóstico de intoxicação por ionóforos.

Palavras-chave: antibióticos, bovino, ionóforo, necrose muscular.

\section{INTRODUCTION}

Ionophore antibiotics (IAs) are therapeutically versatile in veterinary medicine and often usedas feed additives, coccidiostats, antibiotics, rumen $\mathrm{pH}$ adjusters, improving animal performance and weight gain in a livestock production system. Monensin, lasalocid, and salinomycin are IAs frequently used in veterinary clinics (NOGUEIRA et al., 2009; RODER, 2011). Monensin is known to promote rumen microenvironment change in cattle rumen, modifying the proportion of volatile fatty acids (PERRY et al., 1976). Dairy cows fed with sodium monensin supplemented diets have contents of total solids in milk increased; thus, supplementation of early lactating cow diets, with such component can be inherently associated with milk production (POSSATTI, et al., 2015). Moreover, monensin has shown to increase permeability of $\mathrm{Na}^{+}$, $\mathrm{K}^{+}$, and $\mathrm{H}^{+}$ions to muscle cell cytosol with excitatory effects due to depolarization of presynaptic nerve endings (SHERIDAN, 1996) and $\mathrm{Ca}^{++}$influxes, leading to cardiac and skeletal degeneration and necrosis (GUPTA, 2012).

An overdose of IAs can have adverse reactions in cattle, sheep, horses, and other domestic animals, with further fatal outcomes (ROZZA et al., 2006). Cases of IAs poisoning occurs by excessive 
ingestion due to errors in feed mixes and doses, or even supply to susceptible domestic species (BASARABA et al., 1999). This paper described a monensin intoxication outbreak in cattle due to error in monensin addition to mineral supplementation, highlighting clinical, pathological, and direct identification of toxins.

\section{MATERIALS AND METHODS}

A poisoning outbreak was described after calf mortality by a veterinary visit to a ranch in Pires do Rio, state of Goiás, Brazil (altitude: $758 \mathrm{~m}$, latitude: $17^{\circ} 17$ 'S ; and longitude: $48^{\circ} 16^{\prime} \mathrm{W}$ ). An epidemiological evaluation was conducted on nine calves (five symptomatic and four asymptomatic), which were submitted to clinical evaluation after movement stimulation. Blood samples were collected for complete blood count and serum biochemistry for aspartate transaminase (AST), creatine kinase (CK), lactate dehydrogenase (LDH), ionized calcium, and lactate. One symptomatic animal was submitted to necropsy after sudden death. Organ samples were collected for histopathological evaluation (HE and Masson's trichrome stains).

Complete blood count and biochemistry results were analyzed statistically and tested for normality by the Shapiro-Wilk test. If the p-value was $<0.05$, there was no normality. When scores were followed by normality, they were accessed by ANOVA analysis $(\mathrm{p}<0.05 \%)$, and when it did not occur, they were accessed by the Wilcoxon test $\mathrm{P}<0.05 \%$ ).

Samples of liver and skeletal muscle (200 g each) were collected in plastic bags and then were frozen $\left(-20^{\circ} \mathrm{C}\right)$. These were taken from a dead calf for analysis of toxic components by liquid chromatography-mass spectrophotometry (LC-MS/MS). The analyses were carried out in the laboratory "Eurofins do Brasil Análise de Alimentos Ltda." by counting fifteen different coccidiostats, including salinomycin, amprolium, monensin, and lasalocid. Dried-minced samples were homogenized with $1 \mathrm{~mL} 1 \%$ acetonitrile. The homogenate was centrifuged, and the supernatant was resuspended in a mixed solution of acetonitrile: deionized water $(8: 2, \mathrm{v} / \mathrm{v})$. Hexane was added into the solution and centrifuged. Then, the superior phase (with hexane) was discarded and inferior phase used in chromatography analysis (LC-MS/MS) (Agilent Standard Autosampler, Masses ABSciex API 4000 QTRAP). Lastly, analytical results were compared with those from analyses of the fifteen different standard coccidiostats.

\section{RESULTS}

A herd of 900 calves aged 10 to 14 months, was recently introduced into the assessed ranch. The herd was raised on Brachiaria spp. pasture and mixed feed, with protein and mineral supplementation with monensin addition during approximately 20 days. Twenty calf deaths had been observed until the day of the visit. After movement stimulation, clinical findings in calves consisted of muscle weakness, ataxia, stiff gait, locomotion disorders, recumbency, bilateral jugular distention, and death. Thin and weak animals were intensively supplemented ad libitum with the mixed feed previous related, and a high consumption was observed. Complete blood count (CBC) of the reported animals showed no important changes, but abnormal variations in serum to AST, CK, LDH, ionized calcium, and lactate, were observed (Table 1). Although, the means of all parameters were different from reference values, AST was the only with statistical differences between symptomatic and asymptomatic animals.

Two of the five symptomatic animals showed recumbency, jugular distention, ataxia, unwillingness to rise, and one of them died (Figure 1A). This dead animal was submitted to autopsy, showing the following minimum changes: approximately $800 \mathrm{~mL}$ of serous fluid in the thoracic cavity and $100 \mathrm{~mL}$ in the pericardium (Figure 1B). Sections of multiple organs including heart muscle, diaphragm, kidney, liver, spleen, and lung were prepared for histological examination. The relevant findings included diaphragm and cardiac muscle changes featured by multifocal to coalescent areas of necrotizing and degenerative myopathies, as well as myositis with lymphocytic infiltration (Figure $1 \mathrm{C}$ and 1D). Apart from these, no other significant findings were observed.

IA poisoning was presumed based on clinical findings and epidemiological data. By LCMS/MS performed on the frozen samples of liver and skeletal muscle (semitendinosus muscle), abnormal concentration of monensin were revealed, (209.4 $\mu \mathrm{g} / \mathrm{g}$ and $25.5 \mu \mathrm{g} / \mathrm{g}$, respectively- reference values: $0.1 \mu \mathrm{g} / \mathrm{g}$ and $0.05 \mu \mathrm{g} / \mathrm{g}$, respectively).

After diagnosis, diet supply was suspended and animal displacement was recommended to be avoided. After 10 days of diet adjustment, no additional animal deaths were recorded.

\section{DISCUSSION}

Clinical presentations of five calves were similar to those previously reported, such as anorexia, 
Table 1 - Arithmetic means of serum biochemical parameters in symptomatic (five calves) and asymptomatic (four calves) monensinpoisoned calves in a ranch in the state of Goiás, Brazil.

\begin{tabular}{|c|c|c|c|c|c|c|c|c|c|}
\hline Parameter ${ }^{*}$ & RV & TT & Mean & Median & MV & SD & $\mathrm{p}^{* *}$ & $\mathrm{p}^{* * *}$ & $\mathrm{p}^{* * * *}$ \\
\hline \multirow{2}{*}{ AST (UI/L) } & \multirow{2}{*}{$0-132$} & $\mathrm{~S}$ & 219.25 & 256.5 & 12438.91 & 111.52 & \multirow{2}{*}{0.047} & & \multirow{2}{*}{0.2229} \\
\hline & & AS & 94.4 & 76 & 1139.3 & 33.75 & & - & \\
\hline \multirow{2}{*}{ CK (UI/L) } & \multirow{2}{*}{$0-94$} & $\mathrm{~S}$ & 1639.8 & 172 & 7824948.2 & 2797.31 & \multirow[b]{2}{*}{ - } & \multirow{2}{*}{0.5296} & \multirow{2}{*}{0.0008} \\
\hline & & AS & 236.4 & 190 & 39636.8 & 199.08 & & & \\
\hline \multirow{2}{*}{ LDH (UI/L) } & \multirow{2}{*}{$692-1.445$} & $\mathrm{~S}$ & 6031.2 & 3634 & 1765882.7 & 42.01 & \multirow{2}{*}{0.091} & \multirow[b]{2}{*}{ - } & \multirow{2}{*}{0.2095} \\
\hline & & AS & 2413.4 & 2365 & 164792.8 & 405.94 & & & \\
\hline \multirow{2}{*}{ Ionized Calcium $(\mathrm{mmol} / \mathrm{L})$} & \multirow{2}{*}{$2.43-3.10$} & $\mathrm{~S}$ & 1.093 & 1.124 & 0.0102 & 0.1008 & \multirow{2}{*}{0.468} & & \multirow{2}{*}{0.4241} \\
\hline & & AS & 1.042 & 1.055 & 0.0125 & 0.1116 & & - & \\
\hline \multirow{2}{*}{ Lactate (UI/L) } & \multirow{2}{*}{$8.0-12.4$} & $\mathrm{~S}$ & 101 & 85 & 6599.5 & 81.23 & \multirow[b]{2}{*}{ - } & \multirow{2}{*}{0.6004} & \multirow{2}{*}{0.0265} \\
\hline & & AS & 60.4 & 66 & 170.0 & 13.06 & & & \\
\hline
\end{tabular}

TT - treatment; S - symptomatic; AS - asymptomatic; *AST - aspartate transaminase; CK - creatine kinase; LDH - lactate dehydrogenase; MV - mean variation; SD - standard deviation; RV - reference value (KANEKO et al., 1997). $\left.{ }^{* *} \mathrm{ANOVA}-\mathrm{P}<0.05 \%\right)$. ${ }^{* * *}$ Wilcoxon test $-(\mathrm{P}<0.05 \%){ }^{* * * *}$ Shapiro-Wilk test for normality (if $\mathrm{P}<0.05 \%$, there is no normality).

diarrhea, incoordination, stiff gait, reluctance to move, muscle tremors, depression, emaciation, and decubitus. These are frequent clinical changes in cases of ionophore poisoning (GONZALEZ et al., 2005; NOGUEIRA, et al., 2009; RODER, 2011; ROZZA, et al., 2006). Additionally, the absence of other epidemiological factors related to the clinical presentation observed, as absence of toxic plants or previous drug administration that would lead to intoxication disorders with similar clinical presentation, were significative for the diagnosis towards IA intoxication. Ionophore metabolism occurs in the liver and has ionotropic effects on cardiac and skeletal muscles (VAN FLEET et al., 1984). Such clinical signs were acute, but a chronic condition cannot be refuted. This is because muscle injuries can occur by ingesting low doses and are irreversible (GUPTA, 2012). Monensin intake adverse effects have already been reported in cattle ingesting doses above $20 \mathrm{mg} / \mathrm{kg}$ (POTTER et al., 1984), and the first acute intoxication signs begin between 6 and 24 hours after ingestion, usually with fatal outcomes (NOGUEIRA, et al., 2009).

Hematological changes after IA poisoning does not comprise primary or direct responses. However, minor changes in serum enzymes can be used to assess progression or recovery of muscle damage by IA (NOGUEIRA, et al., 2009). Singular changes (e.g., CK, LDH, and AST high levels) can occur in poisoning of this nature (RODER, 2011) and are useful in confirming muscle injury, as observed in this description which were consistent in this type of intoxication. Besides these biomarkers, VARGA et al. (2009) demonstrated that cardiac troponin I (cTnI) is related to myocardial necrosis and myocardial damage severity in monensin-poisoned cattle. Although, it was not analyzed on this case, such biomarkers are clinically useful for confirming poisoning cases.

Minimal macroscopic changes were observed in the necropsied animal. About $100 \mathrm{~mL}$ of serous fluid was reported inside the pericardial sac. Previous reports corroborated the fact that macroscopic lesions are less evident or absent in animals dying within 24 hours after the first clinical signs of AI poisoning (SAFRAN et al., 1993; HALL, 2000). After a serial killing of cattle for monensin poisoning, variable amounts of pale-yellow fluid in the pericardial sac were the most consistent postmortem finding, and a small number of calves showed an increase in thin watery fluid in the abdominal and thoracic cavities (BASARABA et al., 1999). Other post-mortem findings included pale areas in skeletal and myocardial muscle due to degeneration and necrosis, in addition to possible hydropericardium, hydrothorax, and pulmonary edema (NOGUEIRA et al., 2009), which are nonspecific to muscle injuries. Microscopic lesions consisted of regressive changes in myocytes and cardiomyocytes, mainly degeneration and necrosis, with multifocal to coalescent distribution, as commonly reported in IA intoxication cases in cattle (NOGUEIRA et al., 2009; RODER, 2011). In this study, a discrete degree of fibrosis and inflammatory cell infiltration was reported in skeletal muscle of the necropsied calf, 


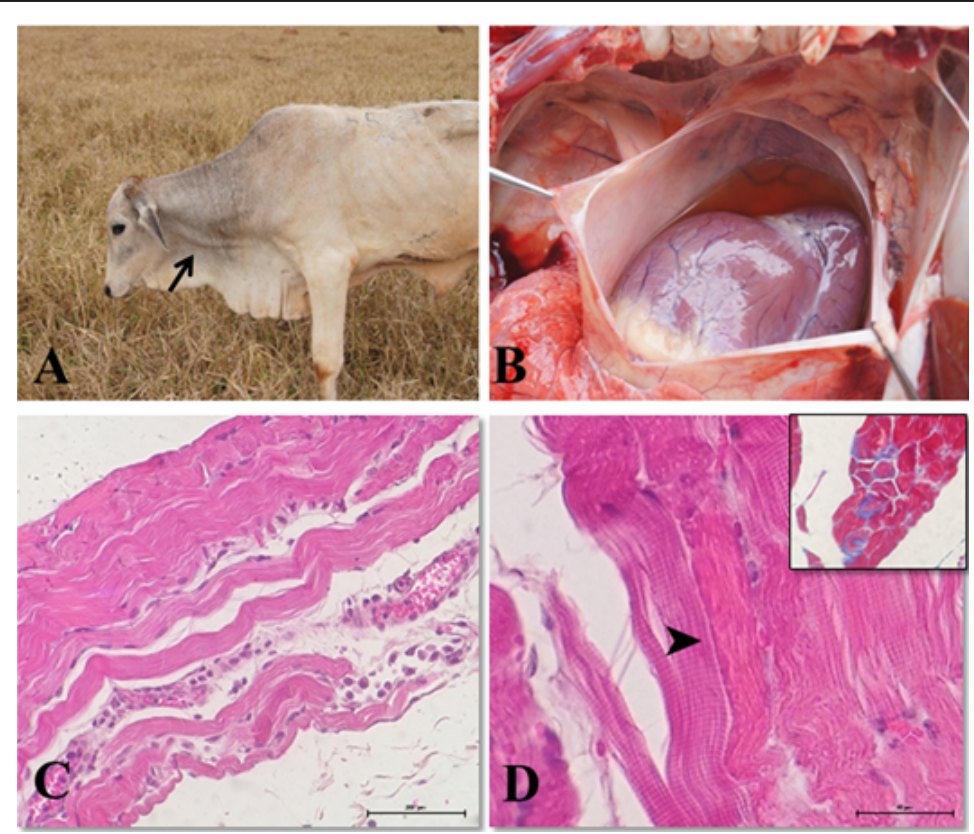

Figure 1 - Monensin outbreak in a ranch in state of Goiás, Brazil. A. Symptomatic calf poisoned by ionophore with jugular distention (arrow) and ataxia. B. Necropsy revealed $100 \mathrm{~mL}$ serous accumulation of fluid in the pericardium. C. Diaphragm from a bovine intoxicated by monensin. Mononuclear inflammatory cell infiltrate, myocyte degeneration, and loss of cellular details (HE, 20x obj). D. Necrotic muscle fiber (arrowhead). Eosinophilic cytoplasm, fiber fragmentation and loss of transverse striations (HE, 40x obj). Detail of multifocal fibrosis in cardiomyocytes, blue areas (Masson's trichrome, 20x obj).

which has already been mentioned by NOGUEIRA et al., 2009 and RODER, 2011.

In the United States, tolerance level to monensin is $0.1 \mu \mathrm{g} / \mathrm{g}$ in the liver and $0.05 \mu \mathrm{g} / \mathrm{g}$ in muscles of cattle ("FDA-CVM, Rumesin", 2018). In Brazil, the "Ministry of Agriculture, Livestock, and Supply" adopts a maximum monensin level of 0.02 $\mu \mathrm{g} / \mathrm{g}$ in the liver of cattle (MAPA, 2017). Increased monensin concentrations were identified in frozen samples from the necropsied animal. The IA toxic doses can also be measured by the median lethal dose $\left(\mathrm{LD}_{50}\right)$ given a concern after exposure to toxic concentrations. Monensin $\mathrm{LD}_{50}$ estimated for cattle is $26.4 \mathrm{mg} / \mathrm{kg}$ body weight (POTTER et al.,1984). In this study, the investigation proposed a monensin dosage error in the feed mix, based in energy and protein supplementation containing monensin both in premix as well as in the mineral supplementation. Both supplementations were produced in house, using owner's formulation that; unfortunately, could not be verified. In loco, the animals showed avid consumption of the ration. Ionophore toxicity outbreaks in cattle are directly related to (1) errors in feed mixing, (2) use of extra-label, accidentally or intentionally, or (3) drug interactions with active compounds such as tiamulin, chloramphenicol, and macrolides (NOVILLA et al., 2003).

\section{CONCLUSION}

Historical data, clinical parameters, serum biochemicals, microscopic muscular lesions, and direct identification of monensin at high concentrations allowed to confirm an outbreak of ionophore antibiotic poisoning in a cattle herd in the state of Goiás, Brazil.

\section{ACKNOWLEDGEMENTS}

The authors would like to thank Conselho Nacional de Desenvolvimento Científico e Tecnológico (CNPq), Coordenação de Aperfeiçoamento de Pessoal de Nível Superior (CAPES) for financial support and Universidade Federal de Goiás (UFG). 


\section{COMMITTEE APPROVAL}

We authors of the article entitled "Outbreak of monensin poisoning in cattle due to supplementation error" declared, for all purposes, the project that gave rise to the present data of the same has not been submitted to the evaluation of the Ethics Committee for Animal Use of the Universidade Federal de Goiás (UFG). However, we are aware of the content of the Brazilians resolutions of the Conselho Nacional de Controle $e$ Experimentação Animal - CONCEA (National Council for Animal Control and Experimentation) <http://www.planalto.gov.br/ ccivil 03/ ato2007-2010/2008/lei/111794.htm>, when involving animals. Thus, the authors assume full responsibility for the presented data and are available for possible questions, should they be required by the competent authorities.

\section{DECLARATION OF CONFLICT OF INTERESTS}

The authors declare no conflict of interest. The funding sponsors had no role in the design of the study; in the collection, analyses, or interpretation of data; in the writing of the manuscript, and in the decision to publish the results.

\section{AUTHORS' CONTRIBUTIONS}

E.S.A. BRITO and V.M.B.D. MOURA contributed to the collection of samples, made contribution to gross and histopathological analysis drafted and rivesised the manuscript and its final cersion. T.G. ANDRADE and C.H.S. de OLIVEIRA contributed to collection of samples, toxicologic analysis as well as drafting and revising the manuscript and its final version.

\section{REFERENCES}

BASARABA, R. J. Toxicosis in cattle from concurrent feeding of monensin and dried distiller's grains Contaminated with Macrolide Antibiotics. Journal of Veterinary Diagnostic Investigation, v.11, p.79-86, 1999. Available from: <https://journals.sagepub.com/doi/abs/10.1 177/104063879901100113 >. Accessed: Nov. 10, 2019. doi: $10.1177 / 104063879901100113$.

FDA-CVM, Rumesin, NADA 095-735. Monensin sodium. Rumesin 80. Freedom of Information Summary, 2018.

GONZALEZ, M. et al. Monensin toxicosis in a dairy herd. Canadian Veterinary Journal, v.46, p.910, 2005. Available from: $<$ https://www.ncbi.nlm.nih.gov/pmc/articles/PMC1255593/>. Accessed: Oct 10, 2019.

GUPTA, R. C. Veterinary toxicology: basic and clinical principles. San Diego: Academic Press, 2012. 1238p.

HALL, J. O. Ionophore use and toxicosis in cattle. Veterinary Clinics of North America: Food Animal Practice, v.16, p.497509, 2000. Available from: <https://www.vetfood.theclinics. com/article/S0749-0720(15)30083-9/abstract>. Accessed: Oct 10, 2019. doi: 10.1016/S0749-0720(15)30083-9.

KANEKO, J. J.; et al.. (eds.) Clinical biochemistry of domestic animals. 5th ed. New York: Academic Press, 1997.
MAPA, Official Diary of The Union, Normative Instruction \#9, February first, p.4-11, 2017.

NOGUEIRA, V. A. et al. Intoxicação por antibióticos ionóforos em animais. Pesquisa Veterinária Brasileira, v.29, n.3, p.191197, 2009. Available from: <https://www.scielo.br/scielo. php script $=$ sci arttext\&pid $=\mathrm{S} 0100-736 \mathrm{X} 2009000300001>$. Accessed: Oct 10, 2019. doi: 10.1590/S0100-736x2009000300001.

NOVILLA, M. et al. Ionophore Diagnostic Manual. Elanco Animal Health, A Division of Eli Lilly and Company, Greenfield, IN, USA, 2003

PERRY, T. W. et al. Effect of monensin on beef cattle performance. Journal of Animal Science, v.42, p.761765,1976. Available from: <https://academic.oup.com/jas/ article-abstract/42/3/761/4697711>. Accessed: Oct 10, 2019. doi: $10.2527 /$ jas $1976.423761 \mathrm{x}$.

POSSATTI, C. D. Sodium monensin on early lactation cows: milk productions and live weigh. Ciência Rural, v.45, n.1, p.92-97, 2015. Available from: <https://www.scielo.br/scielo. php? script $=$ sci_arttext\&pid $=$ S0103-84782015000100092>. Accessed: Oct 10, 2019. doi: 10.1590/0103-8478cr20131684.

POTTER, E. L., et al. Monensin toxicity in cattle. Journal of Animal Science, v.58, p.1499-1511, 1984. Available from: $<$ https://pubmed.ncbi.nlm.nih.gov/6378866/>. Accessed: Nov 10, 2019. doi: $10.2527 /$ jas1984.5861499x.

RODER, J. D. Ionophore toxicity and tolerance. Veterinary Clinics of North America: Food Animal Practice, v.27, p.305-314, 2011. Available from: <https://books.google.com.br/books?hl=pt-BR\&l $\mathrm{r}=\& \mathrm{id}=\mathrm{fHIfwMAWjncC} \& \mathrm{oi}=$ fnd $\& \mathrm{pg}=\mathrm{PA} 305 \& \mathrm{dq}=$ Ionophore + to $\mathrm{xicity}+$ and + tolerance $\&$ ots $=\mathrm{MCoHuh} 9 \mathrm{xdZ} \& \operatorname{sig}=\mathrm{x} 6 \mathrm{NrvbRAQuSJ}$ GD0offa9VfMV1xY\#v=onepage\&q=Ionophore $\% 20$ toxicity $\% 20$ and $\% 20$ tolerance $\& \mathrm{f}=$ false $>$. Accessed: Sep. 10, 2019.

ROZZA, D. B. Monensin toxicosis in water buffaloes (Bubalus bubalis). Journal of Veterinary Diagnostic Investigation, v.18, p.494-496, 2006. Available from: <https://pubmed. ncbi.nlm.nih.gov/17037623/>. Accessed: Oct. 10, 2019. doi: $10.1177 / 104063870601800515$.

SAFRAN, N. Paralytic syndrome attributed to lasalocid residues in a commercial ration fed to dogs. Journal of the American Veterinary Medical Association, v.202, p.1273-1275, 1993. Available from: <https://pubmed.ncbi.nlm.nih.gov/8496084/>. Accessed: Oct 10, 2019.

SHERIDAN, R. E. Protonophore antagonism of botulinum toxin in mouse muscle. Toxicon, v.34, p.849-855, 1996. Available from: $<$ https://pubmed.ncbi.nlm.nih.gov/8875772/>. Accessed: Oct. 10, 2019. doi: 10.16/0041-0101(96)00040-2.

VAN FLEET, J. F. et al. Ultrastructural alterations in skeletal muscle of pigs with acute monensin myotoxicosis. Veterinary Pathology, v.114, p.461-471, 1984. Available from: <https:// www.ncbi.nlm.nih.gov/pmc/articles/PMC1900421/>. Accessed: Oct. 10, 2019.

VARGA, A. et al. Correlation of serum cardiac troponin I and myocardial damage in cattle with monensin toxicosis. Journal of Veterinary Internal Medicine, v.23, p.1108-1116, 2009. Available from: <https://pubmed.ncbi.nlm.nih.gov/19656284/>. Accessed: Oct 10, 2019. doi: 10.1111/j.1939-1676.2009.0355.x. 